
PAJAK DAN RETRIBUSI DAERAH KOTA MANADO

\author{
Meylan Febiola Palenteng ${ }^{1}$, Christian Datu ${ }^{2}$ \\ 1,2Jurusan Akuntansi, Fakultas Ekonomi dan Bisnis, Universitas Sam Ratulangi, J1. Kampus Bahu, Manado, \\ 95115, Indonesia
}

Email : meylanfebiola.07@gmail.com

\begin{abstract}
Regional original income is regional income originating from the results of regional taxes, regional restitution, profits from regionally-owned enterprises, and other legitimate local revenues in exploring funding in the implementation of autonomy as a manifestation of the principle of decentralization. The purpose of this study is to analyze the comparison of the realization of local revenue in the Tax Management and Retribution Agency of the City of Manado during 2016-2017. The method used in this study is descriptive method. It's good that the leadership of the Regional Tax and Retribution Management Board of the City of Manado pays more attention to regional revenue so that there is no significant increase or decrease every year.
\end{abstract}

Keywords : analysis of local revenue, recording, realization

\title{
1. PENDAHULUAN
}

Menurut pasal 1 dalam UU No. 33 Tahun 2004 tentang pertimbangan Keuangan Antara Pusat dan Daerah, PAD atau Pendapatan Asli Daerah merupakan pendapatan yang bersumber dari dalam daerah sesuai peraturan daerah yang ada contohnya hasil pajak daerah, retribusi daerah, pinjaman daerah, dan pendapatan sah daerah lainnya. PAD juga adalah termasuk kumpulan dari Anggaran Pendapatan dan Belanja Daerah (APBD). Berdasarkan UU No. 34 Tahun 2000 Pajak Daerah sebagai kewajiban yang dilakukan oleh wajib pajak atau orang pribadi sebagai iuran yang wajib dibayar kepada daerah dengan tidak mengharapkan imbalan secara langsung karena iuran tersebut untuk pembangunan daerah agar terselenggarakannya program pemerintah. Pendapatan asli daerah sangat berpengaruh untuk berkembang atau tidaknya suatu daerah, dan pendapatan itu berasal dari setiap masyarakat yang tinggal dan membuka usaha diwilayah atau daerah tersebut dengan menbayar pajak. Banyak faktor bisa menyebabkan lalainya masyarakat atau wajib pajak untuk untuk melunaskan kewajiban mereka, dengan adanya rasa tanggung jawab masyarakat atau wajib pajak akan membantu berkembangnya rencana-rencana pembangunan. sebab pajak suatu daerah bertujuan untuk kebaikan umum atau bersama, maka pajak daerah ini sebenarnya bersifat memaksa setiap masyarakat atau wajib pajak untuk bisa melunasi setiap kewajiban pajak mereka tepat pada waktunya.

Keberhasilan otonomi daerah sangat penting bagi pemerintah, itu adalah yang menjadi kunci kesuksesan setiap wilayah untuk memajukan program pemerintah, pembangunan dalam sektor fisik, bahkan sektor ekonomi begitu juga dengan sector-sektor yang lain. Otonomi daerah diatur oleh UU No. 22 Tahun 1999 sekarang telah direvisi menjadi UU No. 32 Tahun 2004 mengatur tentang perimbangan keuangan antara pusat dan daerah, tentu saja ini berarti salah satu peluang bagi daerah untuk lebih meningkatkan setiap potensi terlebih khusus dalam bidang ekonomi. Tipe-tipe penting suatu daerah atau wilayah dapat menjalankan otonom adalah :

1. Keadaan keuangan disuatu daerah atau wilayah, yang artinya daerah atau wilayah tersebut mempunyai keahlian dan kekuasaan untuk menelusuri setiap titik keuangan dan 
memperlakukan keuangannya pribadi atau sendiri agar dapat mengvasilitasi setiap program pemerintah pemerintahan untuk kepentingan kita bersama.

2. Ketidak mandiri hingga mengakibatkan masih tergantung kepada pemerintah pusat untuk mendapatkan bantuan nilainya harus sekecil mungkin oleh karena itu PAD harus didukung oleh kebijakan perimbangan keuangan pemerintah pusat dan daerah agar menjadi sumber keuangan terbesar, ini adalah sebagai prasyarat dalam sistem pemerintahan Negara.

Penerapan atas ipteks ini bertujuan untuk mengetahui setiap selisih realisasi anggaran yang ada di pendapatan asli daerah tahun 2016-2017 hingga bagaimana cara dan proses dalam mencatat pada Badan Pengelola Pajak dan Retribusi Daerah Kota Manado.

\section{TINJAUAN PUSTAKA}

Analisis Pendapatan Asli Daerah. Nurcholis (2007), Menurtnya, PAD (pendapatan asli daerah) merupakan salah satu bentuk pendapayan yang diperoleh dari wajib pajak, retribusi, laba secara sah yangtentunya milik suatu daerah. Muhammad Fauzan (2006), PAD (pendapatan asli daerah) yaitu suatu yang bersumber dari pembiayaan pemerintah daerah, dan bertujuan selalu ingin membangun daerah. Dapat juga dibilang dana yang diberikan berasal dari pajak kembali lagi untuk daerah yang tersebut.

Pencatatan Realisasi Anggaran. Halim (2007) menyatakan pencatatan realisasi anggaran ialah suatu kejadian transaksi yang terjadi dalam artian dokumen dasar pencatatan akuntansi. Hal tersebut juga bisa disimpulkan ialah pencatatan realisasi anggaran penting disebuah laporan keuangan yang dipakai suatu perusahaan atau badan usaha lainnya. Mulyadi (2003) menyatakan pencatatan realisasi anggaran adalah suatu system pencatatan laporan keuangan pemerintah yang juga memberikan suatu informasi tentang realisasi dan anggaran entitas pelaporan dengan cara terhubung untuk suatu periode tertentu.

\section{METODE DAN TEKNIK PENERAPAN IPTEK}

\subsection{Metode Penerapan Ipteks}

Dengan mencapai keberhasilan pengabdian maka metode yang digunakan yaitu metode deskriptif yaitu metode yang mengkaji semua data yang telah diteliti yaitu data diterima dari Badan Pengelola Pajak dan Retribusi Daerah Kota Manado selanjutnya di lihat dan dirincikan untuk bisa menemukan kekeliruan pencatatan penelitian dan menemukan cara yang tepat dalam menyelesaikannya.

\subsection{Teknik Penerapan Ipteks}

Teknik penerapan iptek adalah dengan metode deskriptif yaitu metode yang mengumpulkan data internal perusahaan dan dinyatakan dalam bentuk uraian agar dapat memberikan gambaran objek pengabdian, selanjutnya berdasarkan data tersebut digunakan analisis dengan uraian penjelasan sebagai pelengkap sekaligus penyempurnaan hasil.

\section{HASIL ANALISIS DAN PEMBAHASAN}

\subsection{Gambaran Objek Penerapan Ipteks}

BP2RD Kota Manado lahir sesui dengan peraturan Kota Manado nomor 2 tahun 2011 yaitu megenai pembentujan organisasi dinas-dinas daerah Kota Manado juga dalam peraturan daerah Kota Manado nomor 12 tahun 2000 mengenai peraturan pembentukan dinas-dinas kota manado yang lainnya dijabarkan dalam keputusan Walikota Manado nomor 34 tahun 2001 tentang susunan organisasi BP2RD melakukan separuh tugas rumah tangga daerah dalam bidang apa saja yang didapatkan daerah berserta juga tugas-tugas daerah yang lain yang harus dipertanggungjawabkan kepada Walikota. Dalam melaksanakan Tugas Pokok tersebut Badan Pengelola Pajak dan Retribusi Daerah mempunyai fungsi : 
1. Membuat cara yang tepat untuk kebijakan, pembinaan dan memberi pembimbingan dan juga pengontrolan teknis, tugas-tugasyang lainya yang dipercayakan oleh Bupati yang diatur oleh undang-undang yang sudah di tetapkan.

2. Melakukan registrasi dan pendataan bagi setiap wajib pajakdan retribusi daerah dengan benar-benar dan tidak ada kecurangan.

3. Menyediakan penetapan berapakah pajak dan retribusi daerah dengan benar-benar dan tidak adakecurangan.

4. Menjalankan tugas penagihan bagi wajib pajak secara benar dan tidak ada kecurangan

5. Mengayomi, membimbing, meyakinkan dan menyempurnakan lembaga subak dengan melakukan sosialisasi, penyuluhan, atau hal-hal yang berkaitan lainnya.

6. Membuat setiap tugas perencanaan dan pengendalian operasional terlebih khusus dibidang PAD, pajak bumi bangunan yang ada di desa maupun yang ada dikota bagitu juga bea perolehan atas tanah dan bangunan.

7. Membuat tugas kesekretariatan agar kegiatan dalam organisasi bisa lebih menunjang.

8. Mengusahaakan kemajuan dan peningkatan pendapatan asli daerah yang lebih baik dari tahun ke tahun.

\subsection{Pembahasan}

Tabel 1 : Hasil Perbandingan Penerimaan Pendapatan Daerah

\begin{tabular}{|c|c|c|c|c|}
\hline Uraian Pajak Daerah & $\begin{array}{l}2016 \\
(\text { Rp) } \\
\end{array}$ & $\begin{array}{l}2017 \\
\text { (Rp) } \\
\end{array}$ & $\begin{array}{c}\text { SELISIH } \\
(\mathbf{R p})\end{array}$ & KET \\
\hline Pajak Hotel & 25.425 .453 .862 & 30.499 .296 .864 & 5.073 .843 .002 & Naik \\
\hline Pajak Restoran & 60.607 .630 .932 & 71.905 .821 .095 & 11.298 .190 .163 & Naik \\
\hline Pajak Hiburan & 11.012.273.849 & 11.556.376.025 & 554.102 .536 & Naik \\
\hline Pajak Reklame & 8.922 .985 .528 & 7.842.596.559 & 1.080.388.969 & Turun \\
\hline Pajak Parkir & 8.429 .890 .942 & 10.345 .892 .836 & 1.916.001.894 & Naik \\
\hline Pajak Air Tanah & 1.056.966.368 & 835.608 .882 & 221.387 .486 & Turun \\
\hline Pajak Sarang Burung Walet & 3.760 .000 & 4.960 .000 & 1.200 .000 & Naik \\
\hline $\begin{array}{l}\text { Pajak Mineral Bukan Logam } \\
\text { dan Batuan }\end{array}$ & - & - & - & - \\
\hline ВРНТВ & 28.630 .670 .885 & 52.729 .778 .691 & 24.099.107.806 & Naik \\
\hline Pajak Bumi dan Bangunan P2 & 27.710.018.490 & 27.771.345.028 & 61.326 .538 & Naik \\
\hline $\begin{array}{l}\text { Ret. Pelayanan Persampahan / } \\
\text { Kebersihan }\end{array}$ & 5.503 .980 .000 & 5.642 .945 .000 & 138.965 .000 & Naik \\
\hline $\begin{array}{l}\text { Pajak Penerangan Jalan (PPJ) } \\
\text { PLN }\end{array}$ & 50.435 .147 .574 & 59.724 .290 .560 & 9.289 .115 .986 & Naik \\
\hline Total & 227.738.778.430 & 273.778.991.460 & 53.594.624.380 & Naik \\
\hline
\end{tabular}

Sumber : Rincian Penerimaan Pendapatan Daerah T.A 2016-2017 BP2RD

Tabel 1 menujukan terjadi kenaikan yang cukup besar. Pada tahun 2016 penerimaan pendapatan daerah sebesar $\mathrm{Rp}$ 227.738.778.430 dibandingkan dengan tahun 2017 yaitu sebesar Rp 273.778.991.460. Selisih total yang bisa kita liat sebesar Rp 53.594.624.380.

Berikut ini dijelaskan terjadinya kenaikan atau penurunan realisasi anggaran :

Pendapatan. Seperti aturan pemerintah nomor 71 tahun 2010 mengenai Standar Akuntansi Pemerintah Pendapatan diatur demikian : setiap penerimaan yang berasal dari penerimaan rekening Negara atau Daerah yang keluar langsung berasal dari rekening, itu akan menambah ekuitas dana lancer di suatu periode tahun yang berjalan itu merupakan hak pemerintah juga tidak wajib dibayar oleh pemerintah. 


\section{Pencatatan Pendapatan}

Pajak Hotel. Pajak Hotel mempunyai realisasi anggaran pada tahun 2016 mulai bulan januari - desember dan pada tahun 2017 mulai bulan januari - desember bisa dilihat memiliki selisih harga yang meningkat jauh, yaitu naik antara tahun 2016 - 2017. Penerimaan pendapatan tahun 2016 bertotal $\mathrm{Rp}$ 25.425.453.862 sedangkan pada tahun 2017 penerimaan pendapatannya berjumlah $\mathrm{Rp} 30.499 .296 .864$ perbedaan selisih harga yang terjadi antara kedua tahun tersebut berjumlah Rp 5.073.843.002. Maka dapat disimpulkan di tahun 2016 terjadi kenaikan penerimaan pendapatan realisasi anggaran yang bisa dikatan perbedaannya jauh dibandingkan tahun 2017.

Pajak Restoran. Pajak Restoran mempunyai realisasi anggaran pada tahun 2016 mulai bulan januari - desember dan pada tahun 2017 mulai bulan januari - desember bisa dilihat memiliki selisih harga yang meningkat jauh, yaitu naik antara tahun 2016 - 2017. Penerimaan pendapatan tahun 2016 bertotal Rp 60.607.630.932 sedangkan pada tahun 2017 penerimaan pendapatannya berjumlah $\mathrm{Rp} 71.905 .821 .095$ perbedaan selisih harga yang terjadi antara kedua tahun tersebut ialah berjumlah Rp 11.298.190.163. Maka dapat disimpulkan di tahun 2016 terjadi kenaikan penerimaan pendapatan realisasi anggaran yang bisa dikatan perbedaannya jauh dibandingkan tahun 2017.

Pajak Hiburan. Pajak Hiburan mempunyai realisasi anggaran pada tahun 2016 mulai bulan januari - desember dan pada tahun 2017 mulai bulan januari - desember bisa dilihat memiliki selisih harga yang meningkat jauh, yaitu naik antara tahun 2016 - 2017. Penerimaan pendapatan tahun 2016 bertotal Rp 11.012.273.849 sedangkan pada tahun 2017 penerimaan pendapatannya berjumlah $\mathrm{Rp} 11.556 .376 .025$ perbedaan selisih harga yang terjadi diantara kedua tahun tersebut ialah berjumlah Rp 554.102.536. Maka dapat disimpulkan di tahun 2016 terjadi kenaikan penerimaan pendapatan realisasi anggaran yang bisa dikatan perbedaannya jauh dibandingkan tahun 2017.

Pajak Reklame. Pajak Reklame mempunyai realisasi anggaran pada tahun 2016 mulai bulan januari - desember dan pada tahun 2017 mulai bulan januari - desember bisa dilihat memiliki selisih harga yang menurun jauh, yaitu turun antara tahun 2016 - 2017. Penerimaan pendapatan tahun 2016 bertotal Rp 8.922.985.528 dibandingkan tahun 2017 penerimaan pendapatannya berjumlah Rp 7.842.596.559 perbedaan selisih harga yang terjadi diantara kedua tahun tersebut berjumlah Rp 1.080.388.969. Maka dapat disimpulkan di tahun 2016 terjadi penurunan penerimaan pendapatan realisasi anggaran yang bisa dikatan perbedaannya jauh dibandingkan tahun 2017.

Pajak Parkir. Pajak Parkir mempunyai realisasi anggaran pada tahun 2016 mulai bulan januari - desember dan pada tahun 2017 mulai bulan januari - desember bisa dilihat memiliki selisih harga yang meningkat jauh, yaitu naik antara tahun 2016 - 2017. Penerimaan pendapatan tahun 2016 bertotal Rp 8.429.890.942 sedangkan pada tahun 2017 penerimaan pendapatannya berjumlah Rp 10.345.892.836 perbedaan selisih harga yang terjadi diantara kedua tahun tersebut ialah berjumlah Rp 1.916.001.894. Maka dapat disimpulkan di tahun 2016 terjadi kenaikan penerimaan pendapatan realisasi anggaran yang bisa dikatan perbedaannya jauh dibandingkan tahun 2017.

Pajak Air Tanah. Pajak Air Tanah mempunyai realisasi anggaran pada tahun 2016 mulai bulan januari - desember dan pada tahun 2017 mulai bulan januari - desember bisa dilihat memiliki selisih harga yang menurun jauh, yaitu turun antara tahun 2016 - 2017. Penerimaan pendapatan tahun 2016 bertotal Rp 1.056.966.368 dibandingkan pada tahun 2017 penerimaan pendapatannya berjumlah Rp 835.608.882 perbedaan selisih harga yang terjadi dikedua tahun tersebut berjumlah $\mathrm{Rp}$ 221.387.486. Maka dapat disimpulkan di tahun 2016 terjadi penurunan penerimaan pendapatan realisasi anggaran yang bisa dikatan perbedaannya jauh dibandingkan tahun 2017. 
Pajak Sarang Burung Walet. Pajak Sarang Burung Walet mempunyai realisasi anggaran pada tahun 2016 mulai bulan januari - desember dan pada tahun 2017 mulai bulan januari desember bisa dilihat memiliki selisih harga yang meningkat, yaitu naik antara tahun 2016 2017. Penerimaan pendapatan tahun 2016 bertotal Rp 3.760.000 dibandingkan tahun 2017 penerimaan pendapatannya berjumlah $\mathrm{Rp} 4.960 .000$ perbedaan selisih harga yang terjadi dikedua tahun tersebut ialah berjumlah Rp 1.200.000. Maka dapat disimpulkan di tahun 2016 terjadi kenaikan penerimaan pendapatan realisasi anggaran yang bisa dikatan perbedaannya jauh dibandingkan tahun 2017.

Pajak Mineral Bukan Logam dan Batuan. Pajak Mineral Bukan Logam dan Batuan tidak mempunyai realisasi anggaran pada tahun 2016 mulai januari - desember dan pada tahun 2017 mulai bulan januari - desember bisa dilihat bahwa tidak terjadi aktivitas penerimaan realisasi anggaran. Maka dapat disimpulkan di tahun 2017 - 2016 tidak ada kenaikan atau penurunan penerimaan pendapatan realisasi anggaran.

BPHTB. Pajak BPHTB mempunyai realisasi anggaran pada tahun 2016 mulai bulan januari desember dan pada tahun 2017 mulai bulan januari - desember bisa dilihat memiliki selisih harga yang meningkat jauh, yaitu naik antara tahun 2016 - 2017. Penerimaan pendapatan tahun 2016 bertotal Rp 28.630.670.885 sedangkan pada tahun 2017 penerimaan pendapatannya berjumlah Rp 52.729.778.691 perbedaan selisih harga yang terjadi di kedua tahun tersebut ialah berjumlah Rp 24.099.107.806. Maka dapat disimpulkan di tahun 2016 terjadi kenaikan penerimaan pendapatan realisasi anggaran yang bisa dikatan perbedaannya jauh dibandingkan tahun 2017.

Pajak Bumi dan Bangunan. Pajak Bumi dan Bangunan mempunyai realisasi anggaran pada tahun 2016 mulai bulan januari - desember dan pada tahun 2017 mulai bulan januari desember bisa dilihat memiliki selisih harga yang meningkat jauh, yaitu naik antara tahun 2016 - 2017. Penerimaan pendapatan tahun 2016 bertotal Rp 27.710.018.490 sedangkan pada tahun 2017 penerimaan pendapatannya berjumlah Rp 27.771.345.028 perbedaan selisih harga yang terjadi dikedua tahun tersebut berjumlah Rp 61.326.538. Maka dapat disimpulkan di tahun 2016 terjadi kenaikan penerimaan pendapatan realisasi anggaran yang bisa dikatan perbedaannya jauh dibandingkan tahun 2017.

Retribusi Pelayanan Persampahan / kebersihan. Retribusi Pelayanan Persampahan/Kebersihan mempunyai realisasi anggaran pada tahun 2016 mulai bulan januari - desember dan pada tahun 2017 mulai bulan januari - desember bisa dilihat memiliki selisih harga yang meningkat jauh, yaitu naik antara tahun 2016 - 2017. Penerimaan pendapatan tahun 2016 bertotal $\mathrm{Rp} 5.503 .980 .000$ sedangkan pada tahun 2017 penerimaan pendapatannya berjumlah $\mathrm{Rp} 5.642 .945 .000$ perbedaan selisih harga yang terjadi dikedua tahun tersebut berjumlah Rp 138.965.000. Maka dapat disimpulkan di tahun 2016 terjadi kenaikan penerimaan pendapatan realisasi anggaran yang bisa dikatan perbedaannya jauh dibandingkan tahun 2017.

Pajak Penerangan Jalan. Pajak Penerangan Jalan mempunyai realisasi anggaran pada tahun 2016 mulai bulan januari - desember dan pada tahun 2017 mulai bulan januari - desember bisa dilihat memiliki selisih harga yang meningkat jauh, yaitu naik antara tahun 2016 - 2017. Penerimaan pendapatan tahun 2016 bertotal Rp 50.435.147.574 sedangkan pada tahun 2017 penerimaan pendapatannya berjumlah Rp 59.724.290.560 perbedaan selisih harga yang terjadi diantara kedua tahun tersebut berjumlah Rp 9.289.115.986. Maka dapat disimpulkan di tahun 2016 terjadi kenaikan penerimaan pendapatan realisasi anggaran yang bisa dikatan perbedaannya jauh dibandingkan tahun 2017.

Dalam penerapkan ipteks ini pendapatan asli daerah pada Badan Pengelola Pajak dan Retribusi Daerah Kota Manado pada tahun 2016 sampai tahun 2017 bisa beubah-ubah. Bisa naik dan bisa juga turun, semua ini diakibatkan karena adanya kondisi perekonomian 
nasional yang bisa dikatakan tidak stabil sehingga dampaknya berakibat dan terasa sampai didaerah-daerah. Akan tetapi dari hasil penerimaan realisasi ternyata pajak daerah dan retribusi daerah masih tetap mendominasi ada di Kota manado. Seperti penelitian Rawung (2016) yaitu variable pengeluaran daerah, setiap angka penduduk juga pajak daerah begitu juga dengan retribusi daerah berdampak pada pendapatan asli daerah yang berpengaruh di perekonomian yang belum stabil.

\section{KESIMPULAN DAN SARAN}

\subsection{Kesimpulan}

Kesimpulan atas penerapan ipteks ini adalah :

1. Hasil penelitian ini untuk membandingkan perbandingan pendapatan anggaran realisasi tahun 2016-2017 dan pencatatan pada Badan Pengelola Pajak dan Retribusi Daerah Kota Manado mengalami peningkatan pada realisasi penerimaan ditahun 2017.

2. Pendapatan di Badan Pengelola Pajak dan Retribusi Daerah Kota Manado pada periode tahun 2016-2017 memperlihatkan kenaikan pendapatan anggaran realisasi yang sangat signifikan pada tahun 2017 dibandingkan tahun 2016. Hal tersebut bisa terjadi dikarenakan kondisi perekonomian nasional masih terbilang tidak stabil hingga mengakibatkan berdampak sangat besar dan dirasakan oleh daerah-daerah. Akan tetapi dari setiap sumber penerimaan pajak, Kota Manado yang lebih mendominasi pajak daerah dan retribusi daerah.

\subsection{Saran}

Saran atas penerapan ipteks ini yaitu :

1. Tingkatkan profesionalisme bagi tenaga kerja agar bisa baik lagi dalam bekerja sama untuk mencapai target realisasi dan meningkatkan program kerja yang bisa membuat para wajib pajak bisa lebih memperhatikan kewajiban mereka, agar bisa meningkatkan pendapatan daerah khususnya Kota Manado.

2. Memperhatikan lagi setiap sumber penerimaan pendapatan asli daerah dari tahun ke tahun, agar anggaran realisasi yang ada tetap stabil dan mengalami kenaikan dan penurunan yang sangat signifikan. Terlebih pengawasan secara teknis dan pengendalian harus lebih ditingkatkan lagi.

\section{DAFTAR PUSTAKA}

Dinas Pendapatan Daerah Kota Manado. 2015. Buku Selayang Pandang Dinas Pendapatan Kota Manado.

Effendi, Deviyanti, Ferry, D. Analisis Pendapatan Asli Daerah. Jurnal Ilmu Akuntansi Mulawarman Vol. 2 No. 4. November, 20, 2018

Hestanto. 2018. Management. Pendapatan asli daerah (PAD) menurut para cendikiawan. November, 17, 2018

Mawitjere, P. 2013. Pendapatan asli daerah (PAD). College Journal. 1(1) 2-5 November, 17, 2018

Mokoginta, M dan Novi, S, B. 2017. Ipteks Bagi Masyarakat Perencanaan Pajak Jangka Pendek. Jurnal Ipteks bagi Masyarakat, Vol 01, No. 01,2017,1-13

Nurcholis. 2007. Pendapatan asli daerah. Indonesia student. Jakarta. November, 18, 2018

Pamungkas, D. 2009 Analisis Asli Daerah dan Dana Perimbangan di Kabupaten Klaten.

Skripsi thesis. Universitas Muhammadiyah Surakarta. November, 28, 2018

Pemerintah Kota Manado.2011. Peraturan Kota Manado No. 02 Tahun 2011. Pembentukan

Dinas-dinas Daerah Kota Manado 
Pemerintah Republik Indonesia. 2004. Undang-undang Pemerintah No. 33 Tahun 2004. Mengenai Pertimbangan Keuangan Antara Pusat dan Daerah. Jakarta

Menteri Pendidikan Nasional RI. 2011. Peraturan nomor 17 tahun 2010. Pencegahan dan Penanggulangan Plagiat diperguruan tinggi. Jakarta

Pemerintah Repoblik Indonesia. 2000. Undang-undang Pemerintah No.34 Tahun 2000. Pajak Daerah. Jakarta

Pemerintah Repoblik Indonesia. 2004. Undang-undang Pemerintah No.32 Tahun 2004. Otonomi Daerah. Jakarta

Pemerintah Repoblik Indonesia. 2010. Peraturan Pemerintah No. 71 Tahun 2010. Standar Akuntansi Pemerintahan. Jakarta 